\title{
Blok przedsionkowo-komorowy I stopnia u chorego z dwujamowym kardiowerterem-defibrylatorem - pozornie błahy problem
}

\author{
First degree atrio-ventricular block in a patient with implanted two-chamber \\ cardioverter-defibrillator - an apperently minor problem
}

\author{
Dawid Bąkowski ${ }^{1}$, Beata Wożakowska-Kapłon ${ }^{1,2}$ \\ ${ }^{1}$ Klinika Kardiologii i Elektroterapii Świętokrzyskiego Centrum Kardiologii w Kielcach \\ ${ }^{2}$ Wydział Nauk o Zdrowiu Uniwersytetu Jana Kochanowskiego w Kielcach
}

\section{Streszczenie}

Przedstawiono przypadek 58-letniego pacjenta z kardiomiopatią rozstrzeniową po implantacji dwujamowego kardiowertera-defibrylatora. U chorego stwierdzono niewydolność węzła zatokowego oraz blok przedsionkowo-komorowy I stopnia. Zarówno stymulacja przedsionkowa w trybie AAl, jak i sekwencyjna w trybie DDD były źle tolerowane przez chorego, prowadząc do nasilenia objawów niewydolności serca. Opcję terapeutyczną stanowiło rozszerzenie układu stymulującego do układu resynchronizującego, wiązało się jednak z kolejnym inwazyjnym zabiegiem kardiologicznym. Obecnie różnorodność wszczepialnych urządzeń stymulujących powoduje, że właściwy dobór układu stymulującego, a następnie optymalne programowanie, wymaga uwzględniania wielu, poza obrazem klinicznym, parametrów w badaniach elektrokardiograficznym i echokardiograficznym.

Słowa kluczowe: blok przedsionkowo-komorowy, stymulacja serca, resynchronizacja

Folia Cardiologica 2016; 11, 1: 75-79

\section{Wstęp}

Kardiologiczne urządzenia wszczepialne to ważny element w terapii chorych z zaawansowaną skurczową niewydolnością serca. Ze względu na istotnie zwiększone ryzyko w tej populacji groźnej dla życia arytmii komorowej u większości tych chorych istnieją wskazania do implantacji kardiowertera-defibrylatora (ICD, implantable cardioverter-defibrillator) w prewencji pierwotnej nagłego zgonu sercowego. Niewydolności serca często towarzyszą dysfunkcja węzła zatokowego i zaburzenia przewodzenia przedsionkowo-komorowego oraz (A-V, atrio-ventricular) śródkomorowego. Zaburzenia te niekorzystnie wpływają na parametry hemodynamiczne, nasilając objawy niewydolności serca. Wszczepialne urzą- dzenie stymulujące, a takim jest również każdy ICD, powinno jednocześnie korygować zaburzenia układu bodźcoprzewodzącego, przyczyniając się do polepszenia czynności serca w tym zakresie. Jednak stymulacja serca nie jest zjawiskiem fizjologicznym i jako taka również może się przyczyniać do pogorszenia wydolności serca. Dlatego niezwykle ważny jest zarówno przemyślany wybór układu stymulującego dostosowanego do istniejących zaburzeń chronotropizmu i przewodzenia, jak i optymalne zaprogramowanie urządzenia. Niekorzystna, a wręcz szkodliwa stymulacja komorowa z okolicy koniuszka prawej komory powinna ustąpić miejsca bardziej fizjologicznej stymulacji z okolicy przegrody międzykomorowej czy drogi odpływu prawej komory oraz stymulacji resynchronizującej z udziałem elektrody lewokomorowej.

Adres do korespondencji: lek. Dawid Bąkowski, I Klinika Kardiologii i Elektroterapii, Świętokrzyskie Centrum Kardiologii, ul. Grunwaldzka 45,

25-736 Kielce, e-mail: dgbakowski@gmail.com 


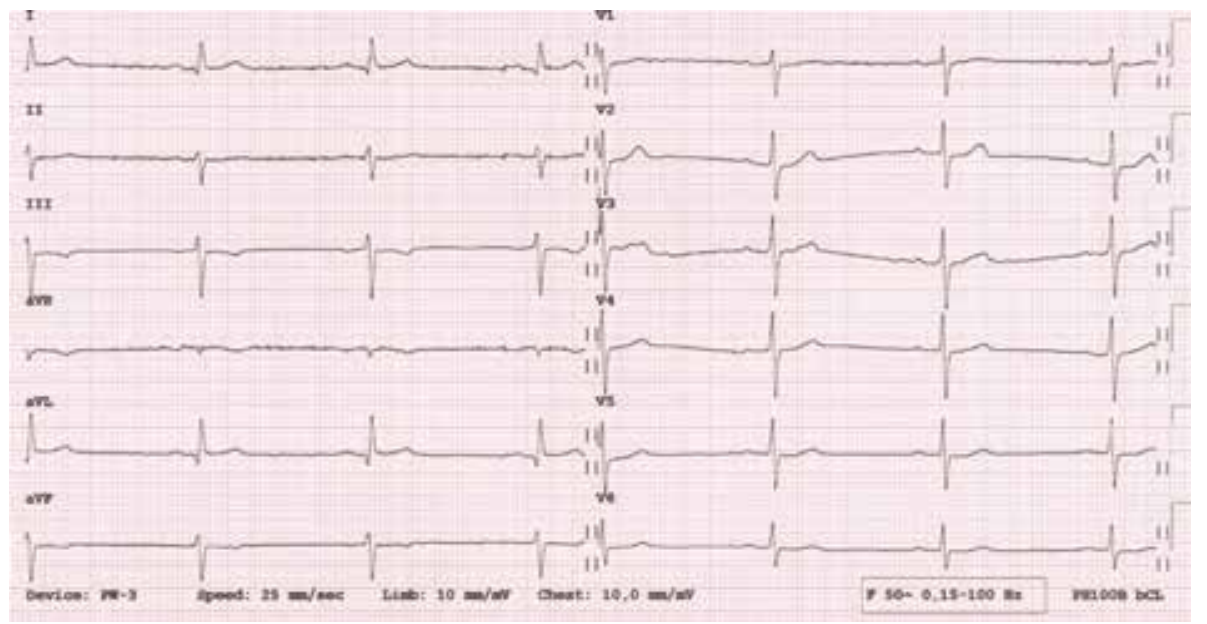

Rycina 1. Bradykardia zatokowa o częstości 40/min. Blok przedsionkowo-komorowy I stopnia (220 ms) i blok przedniej wiązki lewej odnogi pęczka Hisa - zapis po wyłączeniu stymulacji serca

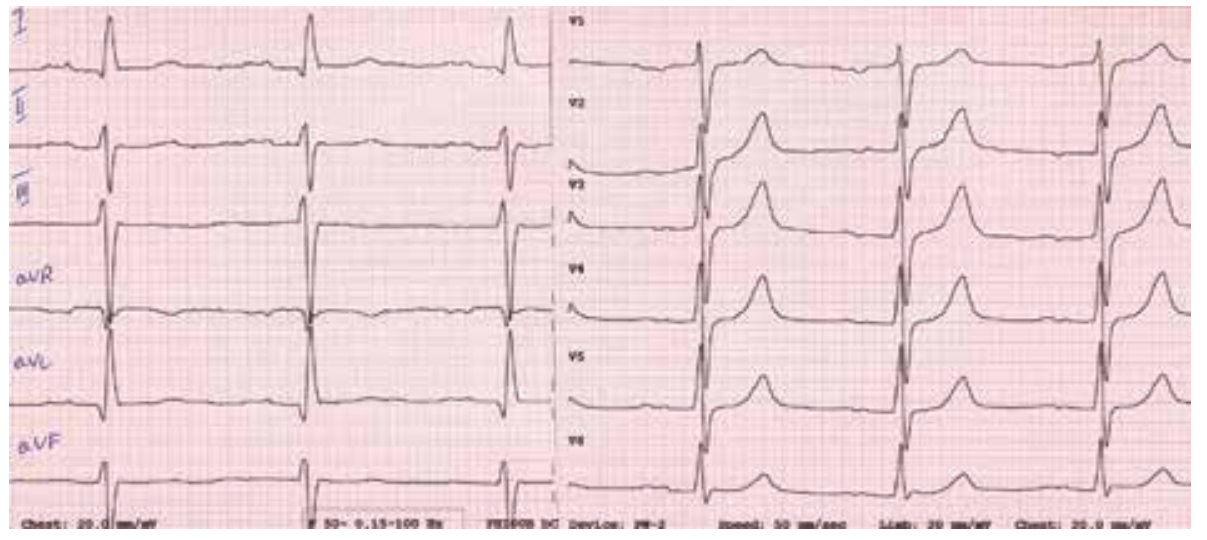

Rycina 2. Stymulacja przedsionkowa AAI z częstością 60/min. Odstęp PR 280 ms. Widoczny dwugarbny załamek P związany z aktywacją prawego i lewego przedsionka. Zapis elektrokardiograficzny z cechą $20 \mathrm{~mm}$ i przesuwem $50 \mathrm{~mm} / \mathrm{s}$

\section{Opis przypadku}

W pracy przedstawiono przypadek 58-letniego mężczyzny z kardiomiopatią rozstrzeniową, najpewniej o etiologii pozapalnej, z frakcją wyrzutową lewej komory (LVEF, left ventricular ejection fraction) wynoszącą 30\%, bez istotnych zmian w tętnicach wieńcowych w koronarografii, po implantacji rok wcześniej dwujamowego ICD (Maximo /I DR ${ }^{\circledR}$, Medtronic) w prewencji pierwotnej nagłego zgonu sercowego. W czasie kolejnej wizyty w poradni kontroli ICD chory zgłosił postępujące zmniejszenie tolerancji wysiłku fizycznego bez istotnych dolegliwości w spoczynku.

W badaniu przedmiotowym nie stwierdzono objawów dekompensacji układu krążenia. Ciśnienie tętnicze wynosiło 120/75 mm Hg. Leczenie farmakologiczne oceniono jako optymalne. W badaniu elektrokardiograficznym (EKG) przy wyłączonej stymulacji serca stwierdzano bradykardię zatokową 40/min, graniczny blok przedsionkowo-komorowy (A-V, atrio-ventricular) I stopnia (odstęp PR 220 ms) oraz blok przedniej wiązki lewej odnogi pęczka Hisa (ryc. 1). $\mathrm{U}$ chorego w ramach stymulacji serca stosowano algorytm preferujący spontaniczne przewodzenie A-V (MVP, managed ventricular pacing), co w praktyce odpowiadało stymulacji serca w trybie AAl. W algorytmie tym pomija się stymulację komór nawet przy znacznie wydłużonym spontanicznym odstępie PR. Dopiero w przypadku zaistnienia bloku A-V II lub III stopnia (brak spontanicznego załamka R po min. 2 z 4 kolejnych załamków P) włącza się sekwencyjna stymulacja DDD z zaprogramowanym opóźnieniem przedsionkowo-komorowym (AVD, A-V delay).

Częstość stymulacji przedsionkowej u omawianego chorego wynosiła 60/min. Przy tej częstości w EKG stwierdzano blok A-V I stopnia z odstępem PR 280 ms (ryc. 2). Mimo tak wydłużonego odstępu PR w badaniu echokardiograficznym nie zobrazowano zaburzenia napływu mitralnego w postaci nakładania się na siebie fal E i A i skrócenia tym samym czasu napełniania lewej komory (ryc. 3). Objętość wyrzutowa lewej komory obliczona metodą doplerowską, przy 


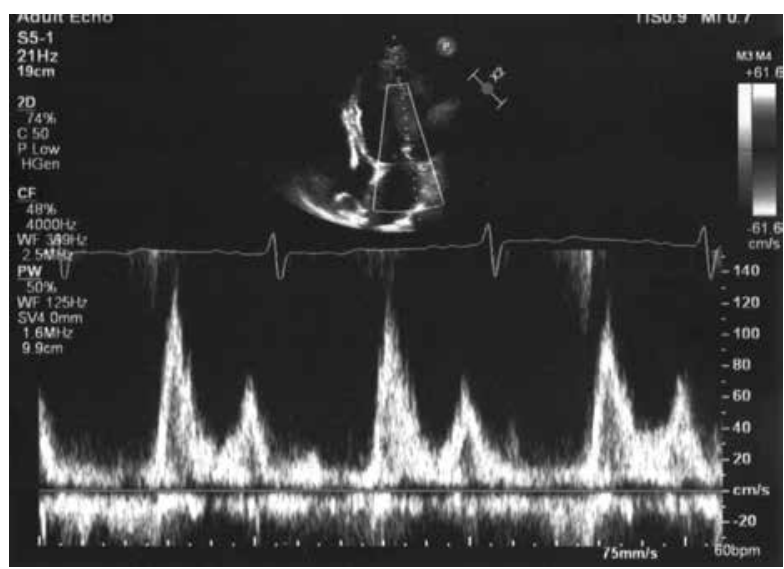

Rycina 3. Napływ przez zastawkę mitralną w czasie stymulacji AAI 60/min (odstęp PR równy 280 ms w zapisie elektrokardiograficznym)

AV VTI (aortic valve velocity time integral) równej $16,3 \mathrm{~cm}$, wynosiła $62 \mathrm{ml}$. Poza tym stwierdzono mitralną falę zwrotną ocenioną na stopień umiarkowany.

Przypuszczano, że poza istotnie zaburzoną czynnością skurczową lewej komory, wynikającą z choroby podstawowej, do nasilenia objawów niewydolności serca może się przyczyniać niewydolność chronotropowa serca. Zwiększono zatem częstość podstawową stymulacji do 70/min, włączając jednocześnie funkcję rate response. $\mathrm{Na}$ kolejną wizytę chory zgłosił się po 7 dniach, podając jeszcze większe pogorszenie tolerancji wysiłku (III klasa wg New York Heart Association [NYHA]). W badaniu EKG stwierdzono stymulację serca AAl 70/min z odstępem PR $320 \mathrm{~ms}$, a w badaniu echokardiograficznym zaobserwowano już wyraźne skrócenie czasu napełniania lewej komory z nakładaniem się fal E i A napływu mitralnego (ryc. 4). Wartość VTI wypływu aortalnego wynosiła $14,4 \mathrm{~cm}$. W czasie zwiększania częstości stymulacji serca (co musiało nastąpić w czasie aktywności chorego z powodu włączonej funkcji R) zauważono również dalsze wydłużenie czasu przewodzenia A-V (przy częstości 80/min PR wynosił 360 ms) oraz dalsze pogarszanie się parametrów hemodynamicznych $w$ badaniu echokardiograficznym - całkowite nałożenie się fal E i A z wybitnym skróceniem czasu napełniania ze zmniejszeniem wartości AV VTI do 11,1 cm (ryc. 5).

Wobec powyższego zrezygnowano $z$ algorytmu preferującego spontaniczne przewodzenie A-V i zaprogramowano stymulacje sekwencyjną dwujamową DDD z częstością podstawową w dzień $70 / \mathrm{min}$, nocną $60 / \mathrm{min}$, z funkcja rate response (ADL, activity of daily living $80 / \mathrm{min}$; USR, upper sensor rate 100/min). Czas AVD ustalono na $150 \mathrm{ms,}$ posługując się metodą elektroechokardiograficzną opracowana przez Rittera. W EKG obserwowano typowe dla stymulacji prawokomorowej istotne poszerzenie zespołów QRS do 200 ms (ryc. 6). Chory zgłosił się na kolejną wizytę po 2 tygodniach, podając dalsze pogarszanie się wydolności fizycznej oraz pojawienie się duszności spoczynkowej

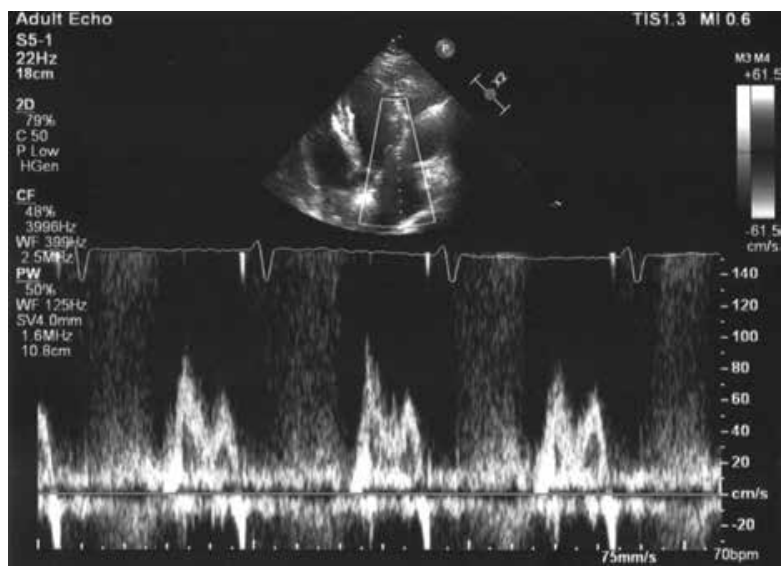

Rycina 4. Napływ przez zastawkę mitralną w czasie stymulacji AAl 70/min (odstęp PR równy 320 ms w zapisie elektrokardiograficznym)

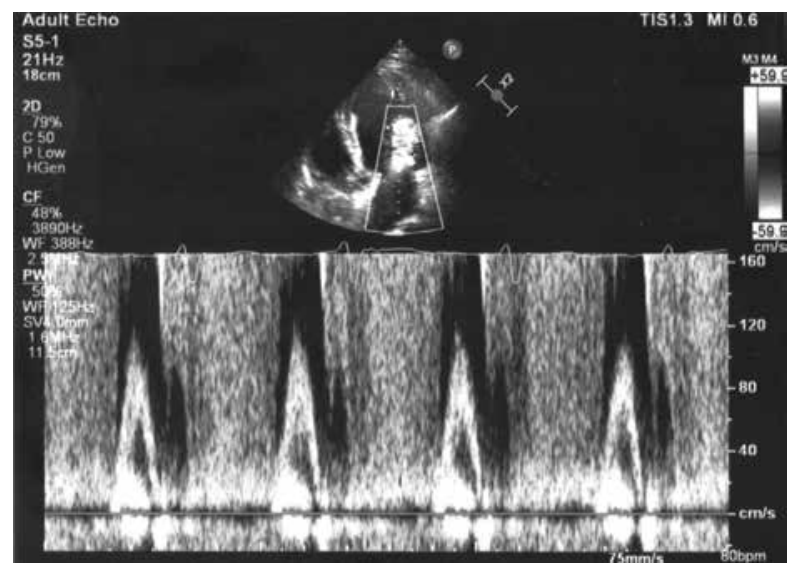

Rycina 5. Napływ przez zastawkę mitralną w czasie stymulacji AAI 80/min (odstęp PR równy 360 ms w zapisie elektrokardiograficznym)

zmuszającej do zwiększenia dawki furosemidu. Wprawdzie w badaniu echokardiograficznym uzyskano wydłużenie napływu mitralnego i rozdzielenie fal E i A, stwierdzono jednak istotne nasilenie niedomykalności zastawki mitralnej z pojawieniem się objawów asynchronii międzykomorowej (czas opóźnienia międzykomorowego [IVD, interventricular delay] $65 \mathrm{~ms}$ ) oraz śródkomorowej (opóźnienie skurczu między segmentem podstawnym przegrody międzykomorowej i ściany bocznej [IVS-LV] $80 \mathrm{~ms}$ ). Stężenie peptydu natriuretycznego typu B (BNP, B-type natriuretic peptide) wynosiło $429 \mathrm{pg} / \mathrm{ml}$.

W związku z obserwowanym brakiem poprawy wydolności serca w czasie stymulacji AAIR z częstością podstawową w dzień $70 /$ min z zachowanym własnym wydłużonym przewodzeniem A-V, jak również dalszego nasilenia niewydolności serca po zmianie stymulacji na DDDR z odtworzeniem optymalnego opóźnienia AVD, powrócono do pierwotnych ustawień ze stymulacją serca AAl 60/min. W tej sytuacji choremu zaproponowano rozszerzenie układu stymulującego serce do układu resynchronizującego $z$ funkcja 


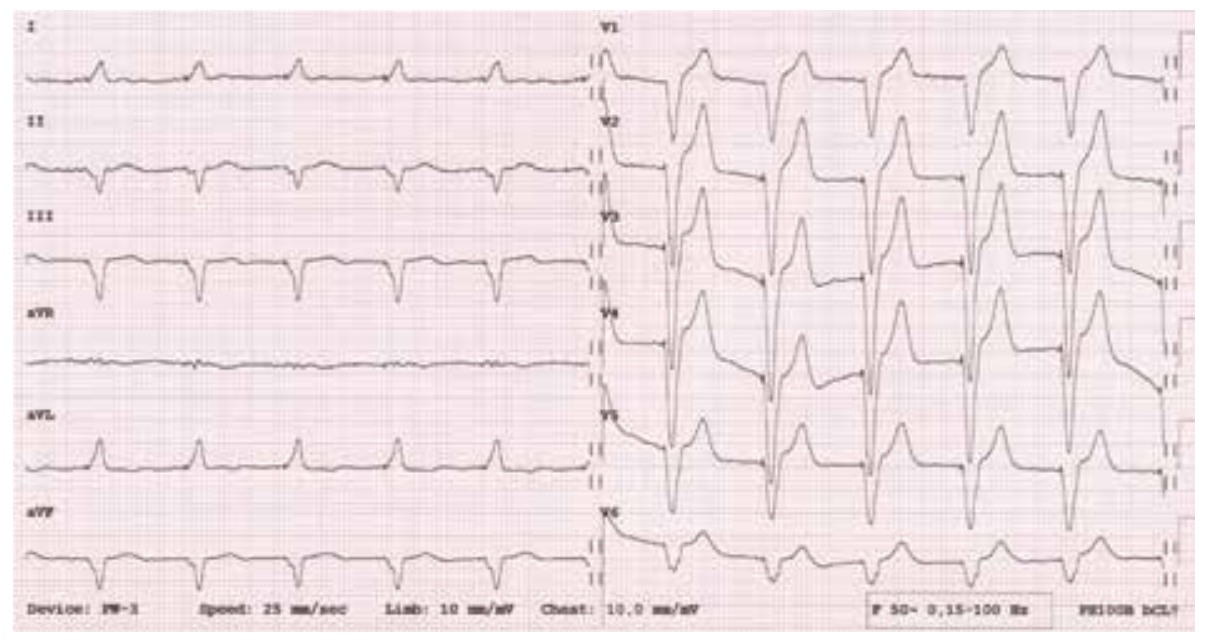

Rycina 6. Stymulacja serca typu DDD 70/min z opóźnieniem przedsionkowo-komorowym wynoszącym 150 ms

defibrylacji (CRT-D, cardiac resynchronization therapy defibrillator), na co nie wyraził zgody.

Po 2 tygodniach chory zgłosił się na kontrolną wizytę, podając poprawę samopoczucia; objawy niewydolności serca uległy zmniejszeniu do II klasy według NYHA. Kontrolne stężenie BNP wynosiło 120 pg/min.

\section{Dyskusja}

W omówionym przypadku choremu z kardiomiopatią rozstrzeniową z istotnie upośledzoną funkcją skurczową lewej komory i objawami niewydolności serca, zgodnie z wytycznymi w prewencji pierwotnej nagłego zgonu sercowego, wszczepiono dwujamowy kardiowerter-defibrylator, ze względu na obserwowaną niewydolność węzła zatokowego. W zapisie EKG u tego pacjenta obserwowano graniczny blok A-V I stopnia oraz blok przedniej wiązki lewej odnogi pęczka Hisa z poszerzeniem zespołów QRS do 114 ms, a więc nie spełniał kryteriów kwalifikacji do implantacji układu resynchronizującego. W stymulacji serca zastosowano w tym przypadku algorytm preferujący spontaniczne przewodzenie A-V, aby uniknąć niepotrzebnej stymulacji prawokomorowej. Celem takiego rozwiązania było uniknięcie niekorzystnych następstw hemodynamicznych związanych ze stymulacją komorową oraz zmniejszenie zużycia baterii stymulatora. W wielu badaniach wykazywano istotne pogarszanie się parametrów czynności skurczowej i rozkurczowej serca oraz występowanie objawów niewydolności serca w wyniku stymulacji z koniuszka prawej komory. Dotyczyło to szczególnie chorych z już istniejącą dysfunkcją skurczową lewej komory. W badaniu DAVID (Dual Chamber and VVI Implantable Defibrillator) [1] stwierdzono częstsze, aż o 61\%, występowanie złożonego punktu końcowego (zgon, hospitalizacja z powodu niewydolności serca) w grupie chorych z większym odsetkiem wystymulowanych pobudzeń komorowych (średnio 58,9\% stymulacji komorowej) niż w grupie z niskim odsetkiem takich stymulacji (średnio 3,51\% stymulacji komorowej). Podobne wyniki uzyskano w badaniu MADIT II (Multicenter Automatic Defibrillator Trial II) [2]. W grupie, w której odsetek stymulacji wynosił 51-100\%, obserwowano o 93\% wyższe ryzyko wystąpienia niewydolności serca i o 50\% więcej adekwatnych interwencji ICD niż w grupie chorych, u których odsetek stymulacji komorowej wynosił 0-50\%. W omawianym przypadku, ze względu na zaawansowaną niewydolność węzła zatokowego, chory niemal w 100\% korzystał ze stymulacji przedsionkowej. Chcąc uniknąć niewydolności chronotropowej serca i dostosować częstość pracy serca do zapotrzebowania metabolicznego, częstość podstawową w czasie czuwania zwiększono do 70/min, jednocześnie programując urządzenie w trybie AAIR, czyli z włączoną i zaprogramowaną adekwatnie do aktywności chorego funkcją rate response. Niestety, zwiększenie częstości stymulacji przedsionków nasilało zaburzenia przewodzenia A-V, wydłużając odstęp PR, co w konsekwencji zaburzyło napływ mitralny, powodując skurcz przedsionków w fazie wczesnego napełniania komór (nałożenie fal E i A). Można przypuszczać, że to właśnie powyższe zaburzenia hemodynamiczne wpływały na nasilenie objawów niewydolności serca. W takiej sytuacji, w celu odtworzenia prawidłowej w czasie sekwencji skurczu przedsionków i komór, program urządzenia zmieniono na DDDR, a AVD ustalono, posługując się znaną regułą elektroechokardiograficzną Ritera [3, 4]. W ten sposób uzyskano prawidłowy napływ mitralny, co potwierdzono w doplerowskim badaniu echokardiograficznym, jednak kosztem wywołania dyssynchronii międzykomorowej (IVD $65 \mathrm{~ms}$ ) i śródkomorowej z poszerzeniem wystymulowanych zespołów QRS w EKG do 200 ms. Objawom zaawansowanej niewydolności serca towarzyszyły zwiększenie się niedomykalności zastawki mitralnej, zmniejszenie objętości wyrzutowej lewej komory i wzrost stężenia BNP. W takiej sytuacji powrócono do pierwotnego programu stymulacji AAI, z częstością podstawową 60/min, która - jak się okazało 
- była najlepiej tolerowana, lecz nieoptymalna. Dlatego choremu zaproponowano rozszerzenie układu do CRT-D z implantacją elektrody lewokomorowej. Warto w tym miejscu zwrócić uwage na odstęp PR i morfologię załamka P przy stymulacji przedsionkowej z częstością 60/min (ryc. 2). Odstęp ten, liczony od początku wystymulowanego załamka P do zespołu QRS, jest wydłużony i wynosi wprawdzie $280 \mathrm{~ms}$, ale widoczny załamek $\mathrm{P}$ będący konsekwencją aktywacji elektrycznej powiększonego zarówno prawego, jak i lewego przedsionka jest dwugarbny i trwa aż 190 ms. Licząc odstęp PR od „drugiego” załamka P będącego skutkiem aktywacji lewego przedsionka, otrzymujemy już znacznie mniejszą wartość 200 ms i najpewniej tym można tłumaczyć zachowany prawidłowy napływ mitralny mimo istotnego wydłużenia odstępu PR.

Zgodnie z wytycznymi European Society of Cardiology (ESC) z 2013 roku, dotyczącymi stymulacji i terapii resynchronizującej [5], rozszerzenie konwencjonalnego układu stymulującego lub układu ICD do układu resynchronizującego CRT/CRT-D zaleca się u pacjentów z niewydolnością serca w III i IV klasie według NYHA mimo optymalnego leczenia z LVEF poniżej 35\%, u których występuje wysoki odsetek stymulacji komorowych (klasa zaleceń IB). Opisany chory z pewnością spełnia powyższe kryteria, biorąc pod uwage występowanie objawowego bloku A-V I stopnia wymagającego sekwencyjnej stymulacji dwujamowej. Analizując powyższy przypadek, można również zadać pytanie, czy u każdego chorego kwalifikowanego do implantacji ICD, z niewydolnością serca i obniżoną LVEF oraz stwierdzonym wydłużonym przewodzeniem przedsionkowo-komorowym czy istotnie obniżonym punktem Wenckebacha, mimo wąskich zespołów QRS, implantację układu CRT-D należy rozważać a priori. Taką możliwość zdają się dawać autorzy wytycznych, wskazując, że terapię resynchronizującą należy rozważyć u chorych z niewydolnością serca i LVEF poniżej $35 \%$ oraz przewidywanym wysokim odsetkiem stymulacji komór (klasa lla/B) [5]. W praktyce jednak dotyczy to głównie pacjentów z bardziej zaawansowanymi blokami A-V II i III stopnia. Opisany przykład wskazywałby, że takie rozwiązanie powinno się brać pod uwagę również u chorych z mniej zaawansowanymi zaburzeniami przewodzenia, co pozwala uniknąć w przyszłości narażenia chorego na kolejne procedury inwazyjne, nie mówiąc o związanych z tym kosztach.

\section{Podsumowanie}

Przy kwalifikacji chorego do implantacji ICD do wyboru są trzy układy - jednojamowy z trybem stymulacji VVI(R), dwujamowy z trybem stymulacji $\mathrm{AAI}(\mathrm{R}) / \mathrm{DDD}(\mathrm{R})$ oraz CRT-D. Dobór właściwej jednostki ma ogromne znaczenie, zważywszy na przyszłe leczenie nierzadko zaawansowanej niewydolności serca oraz zaburzeń rytmu i przewodzenia. Dlatego decyzja ta musi być poprzedzona wnikliwą analizą - nie tylko wskazań do implantacji ICD, ale również rodzaju stymulacji, przewidywanego przebiegu choroby i sposobu jej leczenia.

\section{Konflikt interesów}

Autorzy zgłaszają brak konfliktu interesów.

\section{Abstract}

We present a 58-year-old patient with dilated cardiomyopathy after cardioverter-defibrillator implantation. The patient has sick sinus syndrome and first degree atrio-ventricular block. Both atrial pacing in mode AAI and sequential pacing in mode DDD were poorly tolerated leading to heart failure worsening. The upgrading to resynchronisation therapy was a therapeutic option however requiring another invasive procedure. Presently because of a vast variety of implanted devices, appropriate choice and then optimal programming of the device requires considering not only clinical aspects but also many electrocardiographic and echocardiographic parameters.

Key words: atrio-ventricular block, cardiac pacing, resynchronisation

Folia Cardiologica 2016; 11, 1: 75-79

\section{Piśmiennictwo}

1. Wilkoff B.L., Cook J.R., Epstein A.E. i wsp. Dual chamber pacing or ventricular backup pacing in patients with implantable defibrillator. The Dual Chamber and VVI Implantable Defibrillator (DAVID) Trial. JAMA 2002; 288: 3115-3123.

2. Steinberg J.S., Fischer A., Wang P. i wsp. The clinical implications of cumulitive right ventricular pacing in Multicenter Automatic Defibrillator Trial II. J. Cardiovasc. Electrophysiol. 2005; 16: 359-365.
3. Mitkowski P. Podstawy elektrostymulacji serca - część 3. Czas opóźnienia przedsionkowo-komorowego. Kardiol. Dypl. 2009; 8: 37-41.

4. Ritter P., Dib J.C., Lellevre T. i wsp. Quick determination of the optima $\mathrm{AV}$ delay at rest in patients paced in DDD mode for complete AV block. Eur. J. CPE 1994; 4: A163.

5. Brignole M., Auricchio A., Baron-Esquivas G. 2013 ESC Guidelines on cardiac pacing and cardiac resynchronisation therapy. Eur. Heart J. 2013; 34: 2281-2329. 